\title{
European agroforestry is no universal remedy for biodiversity: a time-cumulative meta-analysis
}

\author{
Anne-Christine Mupepele ${ }^{1,2^{*}}$, Matteo Keller ${ }^{2}$ and Carsten F Dormann ${ }^{2}$
}

\footnotetext{
"Correspondence:

anne-christine.mupepele@biom.uni-

freiburg.de

${ }^{1}$ Nature Conservation and Landscape

Ecology, University of Freiburg,

Tennenbacherstr. 4, 79106 Freiburg,

Germany

${ }^{2}$ Biometry and Environmental

System Analysis, University of

Freiburg, Tennenbacherstr. 4, 79106

Freiburg, Germany

Full list of author information is

available at the end of the article
}

\begin{abstract}
Background: Agroforestry is a production system combining trees with crops or livestock. It has the potential to increase biodiversity in relation to single-use systems, such as pastures or conventional agriculture, by providing a higher habitat heterogeneity. In a literature review and subsequent meta-analysis, we investigated the relationship between biodiversity and agroforestry and critically appraise the underlying evidence of the results.
\end{abstract}

Results: Biodiversity in agroforestry was higher than in conventional agriculture, but could not outcompete pastures, forests and abandoned agroforestry systems. There was no overall biodiversity benefit in agroforestry systems. Data were available for plants, birds, bats and arthropods. Arthropods and birds were the two taxonomic groups profiting from agroforestry systems. A time-cumulative meta-analysis shows that there was no general benefit of biodiversity at any point in the past besides in early 2015. Time-cumulative meta-analysis can unravel missing robustness of meta-analytical results if conclusions alternate between significant to non-significant summary effect sizes over time.

Conclusion: Agroforestry increases biodiversity only in silvoarable systems compared with conventional agriculture. But even this result is based on a small magnitude and single-study effect sizes were heterogeneous with sometimes opposing conclusions. The latter suggests the importance of other usually unmeasured variables, such as landscape parameters or land-use history, influencing biodiversity in agroforestry systems.

Keywords: Species richness; Silvopasture; Silvopastoral; Silvoarable; Arthropods; Birds

\section{Introduction}

Agroforestry is a collective name for diverse land-use systems integrating tree husbandry with livestock or arable cultivation [1, 2]. It is a key historical element of the European landscape currently experiencing changes from traditional systems, e.g. large fruit tree orchards with extensive livestock grazing, to newer approaches, e.g. short rotation coppice in combination with crop rows [3]. Agroforestry is classified into silvopastoral sys- 
tems, grazed by livestock or used for fodder production, and silvoarable systems, in which crops are grown among trees [4]. Fields where trees are grown only at the edge, such as stream side management zones or hedgerows adjacent to arable land, are also occasionally subsumed under agroforestry systems [4]. In these cases, the herbaceous and wooded components are usually not managed together and often have different owners. In our study, trees or shrubs adjacent to fields or pastures are not considered.

Biodiversity is threatened and particularly steep declines have been observed in intensively used agricultural areas [5-8]. Compared to monocultures, agroforestry systems increase heterogeneity in the landscape structure and potentially lead to increased biodiversity [ $5,9-12]$. Demonstrating a clear benefit for biodiversity could favour future subsidies for agroforestry systems by the Common Agricultural Policy or its successor policies [13-17]. The benefits for biodiversity in agroforestry systems have been investigated particularly in the tropics showing that biodiversity can be improved by agroforestry in degraded and intensively cropped areas [18-20]. In the temperate zones, studies for different species groups, such as birds [21] or invertebrates [22] have shown equivocal effects on biodiversity. An earlier meta-analysis found a net increase of biodiversity across taxa and agroforestry systems in Europe, however failed to provide detailed information on the heterogeneity and robustness of their findings [23]. Here we provide an evidence update and a more explicit discussion on biodiversity in comparison to forests and agriculture/pasture and assess the robustness of the results by answering the following research questions: (1) Does agroforestry affect biodiversity? (2) Is biodiversity in agroforestry influenced by other environmental variables, such as differences in taxonomic groups or climatic region? (3) How robust and strong is the underlying evidence of these results?

\section{Materials and Methods}

We review the literature on biodiversity in European agroforestry systems and synthesize the results in a meta-analysis. This review is based on the standards of the Collaboration for Environmental Evidence [24-27]. It further goes beyond these standards by additionally performing a sensitivity analysis with studies weighted based on their evidence to identify the robustness of the results [28].

\section{Literature search}

We used search terms and their synonyms related to 'biodiversity', 'agroforestry' and 'Europe' in the Web of Science to identify the relevant literature (Box 1). Reviews revealed by the Web of Science search were scanned for additional references. In the first screening of articles, we sighted title and abstract and excluded publications that did not fulfil the inclusion criteria (Box 2). In a second screening, we read the full text and applied additional inclusion criteria (Box 2). If an article was included, we extracted the 
Box 1: Search string used in the Web of Science initially in January 2016 with updates in 2018, 2019 and last on 14th February 2020. The search covered the following databases: Web of Science Core Collection, BIOSIS Citation Index, BIOSIS Previews, Current Contents Connect, Data Citation Index, Derwent Innovations Index, $\mathrm{KCl}$-Korean Journal Database, MEDLINE, SciELO Citation Index, Zoological Record. Search options in the Web of Sciences were set to 'all years' and 'all languages'.

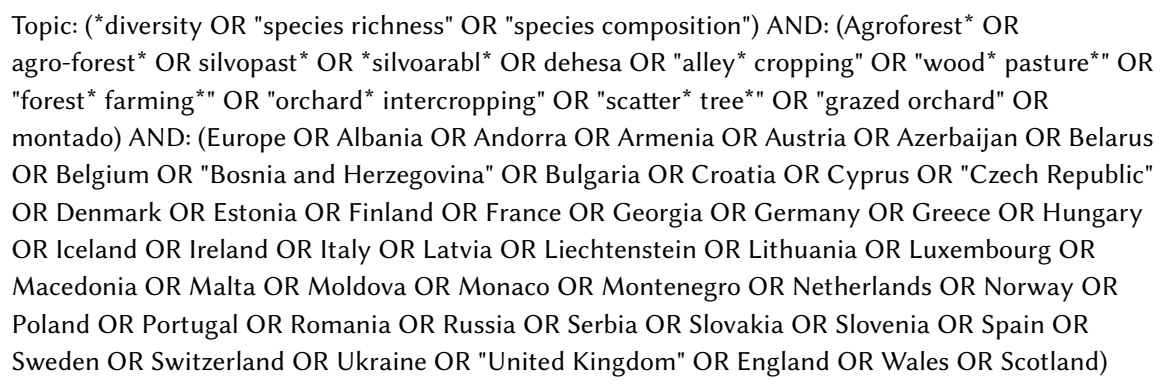

mean diversity, standard deviation and sample size in an agroforestry system and its corresponding control site along with environmental variables (Table 1). WebPlotDigitizer was used to extract data points from figures [29]. Unique combinations of agroforestry system, control type and taxonomic group were considered from each article.

\section{Analysis}

Meta-analysis is based on effect sizes and here we used log response ratios to compare the biodiversity between an agroforestry site and its corresponding control site [30, 31]. The summary effect of agroforestry on biodiversity was estimated by running a random-effect model, with a random effect on the study, and no further fixed effects [32]. Heterogeneity was tested with a $\mathrm{Q}$ test for heterogeneity and additionally given by $I^{2}$, the ratio of heterogeneity (i.e. between-study variability) to the total variability (i.e. sum of between- and within-study variability) $[33,34]$. If heterogeneity accounts for large amounts of the total variability, additional environmental variables (moderators) may improve the model by further explaining parts of the heterogeneity. This was investigated with a mixedeffects model with fixed-effects selection based on a likelihood-ratio test [35]. Marginal $R^{2}$ was given to identify the amount of heterogeneity that could be explained by the selected mixed-effects model [36, 37]. If the mixed-effects model identified categorical environmental variables influencing the agroforestry-biodiversity relationship, a subsequent subgroup meta-analysis was performed to identify under which circumstances agroforestry is beneficial to biodiversity. Analysis was realized in R 4.0.2 using packages 'metafor', 'nlme' and 'MuMIn' [30, 38, 39, see Additional file 5 for details and R code]. 
Box 2: Inclusion criteria for studies to be included in this review.

Inclusion criteria for title and abstract screening

- Study sites are located in Europe. Europe ranges from Iceland to the Ural Mountains and from Norway to the Mediterranean Sea and the Black Sea.

- The study is done in an agroforestry system, whereas agroforestry is defined by an area covered by crops or livestock and trees in an alternating way. Buffer strips and hedgerows only bordering an agricultural field or pasture were not considered.

- The study provides information on biodiversity in an agroforestry system.

Additional inclusion criteria for full-text screening

- The article should be accessible through the subscriptions hold by the University of Freiburg or personal communication with the authors.

- The study should not discuss conceptual approaches or introduce new methods without quantifying biodiversity in agroforestry.

- If a study reviewed other primary studies, references were verified for inclusion.

- Average species richness or another quantifiable biodiversity measure, such as Shannon diversity, needs to be extractable for an agroforestry system and a corresponding control type in relation to their sample size.

\section{Sensitivity analysis}

Studies are traditionally weighted according to their inverse variance. This method has been criticized for being prone to bias especially with small sample sizes [40]. We tested the robustness of the results by adjusting the weighting by the underlying evidence of each study [compare with 41]. For this purpose studies were scaled according to their level of evidence [28]. Publication bias was assessed based on a funnel plot and an Egger's regression test [31, 35, 42].

\section{Results}

The literature search resulted in 1411 records from which 50 articles met all inclusion criteria (Fig. 1, Additional file 1). Unique combinations of agroforestry systems (silvoarable or silvopastoral), control types (forest, agriculture, pasture or abandoned agroforestry systems) and taxonomic groups per study led to 69 effect sizes used in the meta-analysis.

Studies had been conducted in sites all across Europe and covered data from 1984 to 2019 (Fig. 2). The majority of study sites were located in the Mediterranean with 12 studies from Spain, 8 from Portugal, 5 from Italy and one from France and Turkey each. There were fewer studies from the temperate central European climate, characterized by cold winters and summer-green deciduous forests. They ranged from the United Kingdom (6), Romania (4), France (2), Germany (2), Switzerland (2) and Belgium (1) to northern Italy (1). The boreal region was represented by four studies from Sweden and two from Finland.

Agroforestry systems were predominately silvopastoral (36 studies, 52 effect sizes), while silvoarable systems were less often a topic of research (13 studies, 17 effect sizes). The impact of agroforestry on biodiversity was evaluated by comparing agroforestry sys- 
tems to a control type. Most often this control type was a pasture ( 23 effect sizes), followed by forests (21 effect sizes), conventional agricultures, i.e. crop fields, (12 effect sizes) and abandoned agroforestry systems (13 effect sizes).

Biodiversity was measured in different taxonomic groups and reported at various levels of detail across studies. Some studies for example lumped all arthropods, whereas others reported diversity of carabids only. We clustered biodiversity measures into five groups: arthropods, birds, bats, plants and one group with fungi, lichen and bryophytes. Biodiversity effects were mainly measured based on differences in species richness. Five studies with seven effect sizes used other measures, namely family richness [43, 44], log-series $[45,46]$ or Shannon index [47].

\section{Effects of agroforestry on biodiversity}

The results of the meta-analysis show that there is no general benefit of agroforestry systems on biodiversity (summary effect size $=0.1,95 \% \mathrm{Cl}=[-0.03,0.23], z_{d f=68}=$ $1.47, p=0.14$, Additional file 5). The studies' individual effects sizes show substantial between-study variability $\left(\mathrm{Q}=6229, p<0.0001 ; I^{2}=98.9 \%\right.$; Fig. 4.) Some of this heterogeneity was attributed to systematic differences in environmental variables and the 'taxonomic group', 'control type' and 'agroforestry type' could explain $13.5 \%$ of the heterogeneity (marginal $R^{2}$ ).

A subgroup analysis for each agroforestry system, further distinguishing biodiversity effects depending on the control type, revealed that silvoarable systems were significantly more divers than conventional agriculture (Fig. 4b, 'Agriculture' summary effect size $\left.=0.46,95 \% \mathrm{Cl}=[0.1,0.82], z_{d f=11}=2.52, p=0.012\right)$ with 1.6 times more species in the agroforestry system than in conventional agriculture. Comparing the biodiversity of silvoarable systems to forests, they did not differ significantly, but showed a tendency towards higher diversity in forests. In silvopastoral systems none of the subgroup effect sizes was significant (Fig. 4a). Effect sizes were very heterogeneous and with partly opposing effects, such as forests harbouring a higher bird diversity in relation to agroforestry in one study [48, moderate-evidence study] and vice versa in another study [49, moderate-evidence study].

A subgroup analysis of taxonomic groups showed that birds and arthropods are significantly more diverse across all agroforestry systems (Bird summary effect size = $0.23,95 \% \mathrm{Cl}=[0.012,0.44], z_{d f=11}=2.07, p=0.038$; Arthropods summary effect size $\left.=0.3,95 \% \mathrm{Cl}=[0.016,0.59], z_{d f=26}=2.07, p=0.038\right)$. For arthropods a higher resolution was available with subgroups on different taxonomic levels, such as bees or spiders. This increased the number of effect sizes from 27 to 41 as the number of unique combination of taxonomic group and agroforestry system increased. None of the most 
replicated groups, i.e. beetles, bees and spiders, showed a consistent diversity response to agroforestry (Fig. 5).

Sensitivity analysis and the underlying evidence

The quality of studies included in this meta-analysis ranged from weak to strong evidence [compare with 28]. Some studies were based on a replicated and controlled design providing the strongest evidence, whereas others used before-after comparison or an observational gradient. We adjusted the study weights according to their level of evidence to assign weaker studies with a lower weight. The results of the evidence-weighted metaanalysis did not lead to different conclusions and confirmed the results of the traditional inverse-variance-weighted meta-analysis (Level-of-evidence-weighted summary effect size $=0.095,95 \% \mathrm{Cl}=[-0.0063,0.2])$. Beside the weighting of studies, missing studies due to a publication bias is another obstacle for robust meta-analytical results. According to the funnel plot and Egger's regression test, no publication bias is detectable in our data (Additional files 5 and 6, intercept of Egger's regression $=0.77, t=0.03, p=0.98$ ).

Given that an earlier meta-analysis has found a significant effect of agroforestry on biodiversity, we were interested in the change of the conclusion over time [23]. A cumulative meta-analysis shows that there is a tendency of agroforestry to be beneficial across time. But only in 2015, when the studies from Garrido-Jurado et al. [50] and Rossetti et al. [51] were added, the confidence interval was above zero (Fig. 6). A meta-analysis conducted in early 2015 would have resulted in an overall significant positive effect of agroforestry on biodiversity. During all other moments between 1991 and today, there is no general beneficial effect of agroforestry for biodiversity, and the conclusion remains robust over the time. Another possible bias could have been introduced by systematically investigating a particular taxonomic group during a certain time period, e.g. a peak of bird studies in the 90s. Taxonomic groups, however, ranged across the whole time period and did not cluster and as such bias the results (Fig. 6, colour code).

\section{Discussion}

European silvoarable systems host higher biodiversity than conventional agriculture, but show a tendency towards lower diversity than forests. In silvopastoral systems there was no evident benefit over either single-use system. Abandoning traditional agroforestry systems and leaving them to shrub encroachment and natural succession did not increase or reduce biodiversity systematically, such as suggested in other studies and is likely to depend on the number of years they were left abandoned [52, 53]. Birds and arthropods were the taxonomic groups with significantly higher diversity in an agroforestry system. The higher diversity of arthropods in agroforestry could not be traced back to any particular subgroup such as beetles, spiders or bees. Even within the taxonomic subgroups effects were heterogeneous. Spider diversity, for example, was found to be higher in agro- 
forestry compared to a forest in one study [54, moderate-evidence study], but showed the opposite effect in another study [55, weak-evidence study].

Agroforestry covers around $10 \%$ of the agricultural area in the European Union [15]. Among them are traditional and very long established agroforestry sites, such as the Mediterranean Dehesas and Montado, traditional Spanish and Portugese silvopastures [3]. Land-use history, i.e. the age of the agroforestry system and the previous land-use type, may have a strong impact which is hardly reported or even known by the primarystudy authors [20]. As such an older agroforestry system may harbour a different biodiversity than a newly established one; and the same holds for an old-grown forest relative to a more intensively managed younger forest site.

Additional unmeasured drivers operating at the landscape scale may equally determine the biodiversity. The implementation of agroforestry at the field scale does not guarantee the viability of populations of tree-dependent species, but could host these species if additional forest patches are found nearby [56,57]. Invertebrates for example profit from a diverse landscape beyond the field scale $[58,59]$. Our conclusion are largely based on species richness comparison; communities may well differ in their composition beyond richness [compare e.g. 22, 60, 61].

Robustness of meta-analytical results

Meta-analysis of systematically searched literature provides evidence that is stronger than individual studies, unsystematic literature searches and qualitative synthesis [28, $62,63]$. Conclusion drawn from a meta-analysis nevertheless depend on the robustness of the result, i.e. whether minor changes, such as alternating the weighting, could reverse the conclusion. Weighting of studies traditionally occurs by inverse variance without considering the differences in study quality and design. In previous work, the underlying evidence and thus the reliability of individual study results has shown to be distinct depending on their study design $[64,65]$. Weighting studies proportional to the evidence underlying each individual study is an alternative to the traditional weighting. In our case, results did not change with the alternative weighting approach, but can confirm the robustness of our conclusions.

Meta-analysis has established in ecology and as such updates of already existing metaanalyses can show how and whether conclusions may change over time. In a cumulative meta-analysis, adding new studies according to their publication date, we did not observe a declining effect as observed in other meta-analyses, but the effect remained stable despite very heterogeneous individual study results [66]. In our study we also found that other environmental variables have an influence on the agroforestry-biodiversity relationship. Meta-analysis builds on what is found in the literature, and additional categorical environmental variables used as moderators in meta-analytical models are rarely bal- 
anced. The results of our analysis is robust over time and adding new studies is unlikely to impact the results [67], but systematically adding studies on silvoarable systems, which in the current meta-analysis make up one third of silvopastoral-study contribution, could well influence the results. An increasing number of silvoarable studies may drag the overall effect size further towards the positive end and eventually turn the combined result to be significantly positive. Given that silvopastoral systems are dominant in Europe, we are nevertheless convinced that the ratio of silvopastoral and silvoarable studies in our meta-analysis reflects the proportion in which agroforestry systems in Europe occur and provide representative results [15].

Reproducibility of results is a sign of robustness, but challenging and often frail $[68,69]$. The present meta-analysis and the analysis from Torralba et al. [23] have resulted in different conclusions as we failed to reproduce their results. While Torralba et al. [23] concluded that agroforestry has a positive effect on biodiversity in general, we could confirm a benefit only in relation to conventional agriculture. A possible explanation is the different set of studies used in their meta-analysis. Their definition of agroforestry includes studies on hedgerows and woody riparian buffers bordering agricultural field, which we did not consider as agroforestry as they are not actually under silvicultural use. They have also missed study results from biodiversity studies that reported disadvantages of agroforestry [e.g. 70, 71]. Successfully consolidating different results could be achieved by clearly communicating the context in which they apply, providing code and data used in the analysis to posthoc identify differences, and a ranking scale communicating, how confident scientists are with their statements. This is desirable to support decision makers, and has been demonstrated for the policy-relevant IPCC reports [28, 72, 73]. In this specific case, where reviews with the same attempt on similar data yield different results, such a confidence statement may indicate that both reviews are indeed very similar in their assessment. In a subgroup analysis of Torralba et al. [23] distinguishing between fungi, arthropods, plants and birds, only birds were significantly positive, which we could confirm in our analysis. In contrast to their results, we have to emphasize that results are heterogeneous. Our review suggests weak effects, and we are only moderately confident about these findings, supposing that the main driver for biodiversity cannot be found in agroforestry but may lie at the landscape scale or be dependent on land-use history.

\section{Conclusion}

Agroforestry increases biodiversity in silvoarable systems compared to agriculture and in general for birds and arthropods, but benefits were small and there was no overall positive effect of agroforestry on biodiversity. Outcomes were influenced by the heterogeneity of effect sizes and silvopastoral systems did not show a benefit over either single-use system. While previous reviews were enthusiastic and considered agroforestry to have led to an 
increase in biodiversity [23], we need to call for caution. In the present evidence assessment, we have identified only few studies providing results based on strong evidence and have found a heterogeneous picture, suggesting other variables to interact with positive or negative effects from agroforestry. Systematic reviews and meta-analyses are providing the best available evidence, but they do not automatically guarantee reproducibility. They depend on the quality, quantity and comparability of studies used in the analysis. We suggest to resolve these issues by a detailed reporting (1), data provision (2) and the communication of heterogeneity (3). Our study provides results embedded in the context in which agroforestry can lead to a benefit for biodiversity. The use of these results can enrich the discussion on how future subsidies from the Common Agricultural Policy of the European Union can further incorporate agroforestry measures. Future studies on landscape parameters and land-use history are required to disentangle the context in which agroforestry is beneficial for biodiversity.

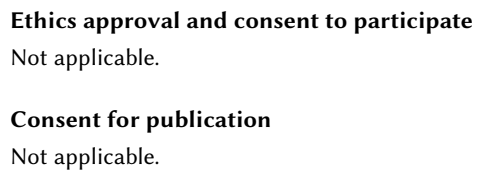

\section{Acknowledgements}

We thank authors of primary studies used in this article to contribute to our meta-analysis by sharing their data and providing additional information to their publications. We also want to thank Amelie Göbel who has initiated this project with her master thesis and provided the evidence assessment of some of the primary studies. We are grateful to the initiative 'Publication Partners during the Covid-19 lockdown' and our publication partners Dominic Andreas Martin for the wonderful figure design and comments on earlier versions and Jonathan Spencer for text editing.

Author details

${ }^{1}$ Nature Conservation and Landscape Ecology, University of Freiburg, Tennenbacherstr. 4, 79106 Freiburg, Germany.

${ }^{2}$ Biometry and Environmental System Analysis, University of Freiburg, Tennenbacherstr. 4, 79106 Freiburg, Germany.

\section{References}

1. Lundgren, B.: Introduction. Agroforestry Systems 1(1), 3-6 (1982). doi:10.1007/BF00044324

2. FAO: Agroforestry and Tenure vol. 8, p. 40. Forestry Working Paper, Rome (2019). http://www.fao.org/3/ca4662en/CA4662EN.pdf

3. Nerlich, K., Graeff-Hönninger, S., Claupein, W.: Agroforestry in Europe: a review of the disappearance of traditional systems and development of modern agroforestry practices, with emphasis on experiences in Germany. Agroforestry Systems 87(5), 1211 (2013). doi:10.1007/s10457-013-9618-9 
4. Mosquera-Losada, M.R., McAdam, J.H., Romero-Franco, R., Santiago-Freijanes, J.J., Rigueiro-Rodriguez, A.: Definitions and Componentns of Agroforestry Practices in Europe. In: Rigueiro-Rodriguez, A., McAdam, J., Mosquera-Losada, M.R. (eds.) Agroforestry in Europe: Current Status and Future Prospects, p. 3. Springer, Dordrecht (2009). Chap. 1

5. Benton, T.G., Vickery, J.A., Wilson, J.D.: Farmland biodiversity: Is habitat heterogeneity the key? Trends in Ecology and Evolution 18(4), 182-188 (2003). doi:10.1016/S0169-5347(03)00011-9. arXiv:1011.1669v3

6. Beckmann, M., Gerstner, K., Akin-Fajiye, M., Ceauşu, S., Kambach, S., Kinlock, N.L., Phillips, H.R.P., Verhagen, W., Gurevitch, J., Klotz, S., Newbold, T., Verburg, P.H., Winter, M., Seppelt, R.: Conventional land-use intensification reduces species richness and increases production: A global meta-analysis. Global Change Biology 25(February), 1941-1956 (2019). doi: $10.1111 /$ gcb.14606

7. Homburg, K., Drees, C., Boutaud, E., Nolte, D., Schuett, W., Zumstein, P., Ruschkowski, E., Assmann, T.: Where have all the beetles gone? Long-term study reveals carabid species decline in a nature reserve in Northern Germany. Insect Conservation and Diversity 12, 268-277 (2019). doi:10.1111/icad.12348

8. IPBES: Summary for policymakers of the global assessment report on biodiversity and ecosystem services of the Intergovernmental Science-Policy Platform on Biodiversity and Ecosystem Services. Technical Report May 2019, Intergovernmental Science- Policy Platform on Biodiversity and Ecosystem Services (2019)

9. Báldi, A.: Habitat heterogeneity overrides the species-area relationship. Journal of Biogeography 35(4), 675-681 (2008). doi:10.1111/j.1365-2699.2007.01825.x

10. Maskell, L.C., Botham, M., Henrys, P., Jarvis, S., Maxwell, D., Robinson, D.A., Rowland, C.S., Siriwardena, G., Smart, S., Skates, J., Tebbs, E.J., Tordoff, G.M., Emmett, B.A.: Exploring relationships between land use intensity, habitat heterogeneity and biodiversity to identify and monitor areas of High Nature Value farming. Biological Conservation 231(July 2018), 30-38 (2019). doi:10.1016/j.biocon.2018.12.033

11. Bhagwat, S.A., Willis, K.J., Birks, H.J.B., Whittaker, R.J.: Agroforestry: a refuge for tropical biodiversity? Trends in Ecology and Evolution 23(5), 261-267 (2008). doi:10.1016/j.tree.2008.01.005

12. Fagerholm, N., Torralba, M., Burgess, P.J., Plieninger, T.: A systematic map of ecosystem services assessments around European agroforestry. Ecological Indicators 62, 47-65 (2016). doi:10.1016/j.ecolind.2015.11.016

13. McAdam, J.H., Burgess, P.J., Graves, A.R., Rigueiro-Rodriguez, A., Mosquera-Losada, M.R.: Classifications and functions of agroforestry systems in Europe. In: Rigueiro-Rodríguez, A., McAdam, J., Mosquera-Losada, M.R. (eds.) Agroforestry in Europe: Current Status and Future Prospects, p. 21. Springer, Dordrecht (2009). Chap. 2

14. Palma, J., Graves, A.R., Burgess, P.J., van der Werf, W., Herzog, F.: Integrating environmental and economic performance to assess modern silvoarable agroforestry in Europe. Ecological Economics 63(4), 759-767 (2007). doi:10.1016/j.ecolecon.2007.01.011

15. den Herder, M., Moreno, G., Mosquera-Losada, R.M., Palma, J.H.N., Sidiropoulou, A., Santiago Freijanes, J.J., Crous-Duran, J., Paulo, J.A., Tomé, M., Pantera, A., Papanastasis, V.P., Mantzanas, K., Pachana, P., Papadopoulos, A., Plieninger, T., Burgess, P.J.: Current extent and stratification of agroforestry in the European Union. Agriculture, Ecosystems and Environment 241, 121-132 (2017). doi:10.1016/j.agee.2017.03.005

16. Mosquera-Losada, M.R., Santiago-Freijanes, J.J., Rois-Díaz, M., Moreno, G., Herder, M.D.: Agroforestry in Europe: A land management policy tool to combat climate change. Land Use Policy 78(July), 603-613 (2018). doi:10.1016/j.landusepol.2018.06.052

17. Santiago-Freijanes, J.J., Pisanelli, A., Rois-Díaz, M., Aldrey-Vázquez, J.A., Rigueiro-Rodríguez, A., Pantera, A., Vityi, A., Lojka, B., Ferreiro-Domínguez, N., Mosquera-Losada, M.R.: Agroforestry development in Europe: Policy issues. Land Use Policy 76(March), 144-156 (2018). doi:10.1016/j.landusepol.2018.03.014

18. De Beenhouwer, M., Aerts, R., Honnay, O.: A global meta-analysis of the biodiversity and ecosystem service benefits of coffee and cacao agroforestry. Agriculture, Ecosystems and Environment 175, 1-7 (2013). doi:10.1016/j.agee.2013.05.003

19. Santos, P.Z.F., Crouzeilles, R., Sansevero, J.B.B.: Can agroforestry systems enhance biodiversity and ecosystem service provision in agricultural landscapes? A meta-analysis for the Brazilian Atlantic Forest. Forest Ecology and Management 433, 140-145 (2019). doi:10.1016/j.foreco.2018.10.064

20. Martin, D.A., Osen, K., Grass, I., Hölscher, D., Tscharntke, T., Wurz, A., Kreft, H.: Land-use history determines ecosystem services and conservation value in tropical agroforestry. Conservation Letters e12740 (2020). doi:10.1111/conl.12740

21. Bohada-Murillo, M., Castaño-Villa, G.J., Fontúrbel, F.E.: The effects of forestry and agroforestry plantations on bird diversity: A global synthesis. Land Degradation and Development (November 2018), 1-9 (2019). doi:10.1002/ldr.3478

22. Boinot, S., Poulmarc'h, J., Mézière, D., Lauri, P.É., Sarthou, J.P.: Distribution of overwintering invertebrates in temperate agroforestry systems: Implications for biodiversity conservation and biological control of crop pests. Agriculture, Ecosystems and Environment 285(August), 106630 (2019). doi:10.1016/j.agee.2019.106630

23. Torralba, M., Fagerholm, N., Burgess, P.J., Moreno, G., Plieninger, T.: Do European agroforestry systems enhance biodiversity and ecosystem services? A meta-analysis. Agriculture, Ecosystems \& Environment 230, 150-161 (2016). doi:10.1016/j.agee.2016.06.002

24. Pullin, A.S., Stewart, G.B.: Guidelines for systematic review in conservation and environmental management. Conservation Biology 20(6), 1647-1656 (2006)

25. Collaboration for Environmental Evidence: Guidelines and Standards for Evidence synthesis in Environmental Management. Technical report, Bangor, UK, Version 5.0 (2018). 
http://www.environmentalevidence.org/information-for-authors

26. Pullin, A., Frampton, G., Jongman, R., Kohl, C., Livoreil, B., Lux, A., Pataki, G., Petrokofsky, G., Podhora, A., Saarikoski, H., Santamaria, L., Schindler, S., Sousa-Pinto, I., Vandewalle, M., Wittmer, H.: Selecting appropriate methods of knowledge synthesis to inform biodiversity policy. Biodiversity and Conservation 25(7), 1285-1300 (2016). doi:10.1007/s10531-016-1131-9

27. Dicks, L.V., Wright, H.L., Ashpole, J.E., Hutchison, J., McCormack, C.G., Livoreil, B., Zulka, K.P., Sutherland, W.J.: What works in conservation? Using expert assessment of summarised evidence to identify practices that enhance natural pest control in agriculture. Biodiversity and Conservation 25(7), 1383-1399 (2016). doi:10.1007/s10531-016-1133-7

28. Mupepele, A.-C., Walsh, J.C., Sutherland, W.J., Dormann, C.F.: An evidence assessment tool for ecosystem services and conservation studies. Ecological Applications 26(5), 1295-1301 (2016). doi:10.1890/15-0595

29. Rohatgi, A.: WebPlotDigitizer - Extract data from plots, images, and maps. Version 4.0 (2017)

30. Viechtbauer, W.: Conducting Meta-Analyses in R with the metafor Package. Journal of Statistical Software 36(3), 1-48 (2010)

31. Koricheva, J., Gurevitch, J., Mengersen, K.: Handbook of Meta-analysis in Ecology and Evolution, p. 498. Princeton University Press, Princeton and Oxford, UK (2013). http://books.google.com/books?id=l3oXBPrOkuYC\&pgis=1

32. Gurevitch, J., Nakagawa, S.: Research synthesis methods in ecology. In: Ecological Statistics: Contemporary Theory and Application. Princeton University Press, Princeton and Oxford (2015). Chap. 9

33. Cochran, W.G.: The combination of estimates from different experiments. Biometrics 10, 1001-129 (1954)

34. Higgins, J.P.T., Thompson, S.G.: Quantifying heterogeneity in a meta-analysis. Statistics in Medicine 21(11), 1539-1558 (2002). doi:10.1002/sim.1186

35. Nakagawa, S., Santos, E.S.A.: Methodological issues and advances in biological meta-analysis. Evolutionary Ecology 26(5), 1253-1274 (2012). doi:10.1007/s10682-012-9555-5

36. Nakagawa, S., Schielzeth, H.: A general and simple method for obtaining R2 from generalized linear mixed-effects models. Methods in Ecology and Evolution 4(2), 133-142 (2013). doi:10.1111/j.2041-210x.2012.00261.x

37. Martin, P.A., Newton, A.C., Pfeifer, M., Khoo, M.S., Bullock, J.M.: Impacts of tropical selective logging on carbon storage and tree species richness: A meta-analysis. Forest Ecology and Management 356, 224-233 (2015). doi:10.1016/j.foreco.2015.07.010

38. Bartoń, K.: MuMIn: Multi-Model Inference. Technical report, R package version 1.43 .15 (2019)

39. Pinheiro, J.C., Bates, D.M., DebRoy, S., Sarkar, D.: nlme: Linear and Nonlinear Mixed Effects Models (2020). https://cran.r-project.org/package=nlme

40. Doncaster, C.P., Spake, R.: Correction for bias in meta-analysis of little-replicated studies. Methods in Ecology and Evolution 9(3), 634-644 (2018). doi:10.1111/2041-210X.12927

41. Mupepele, A.-C., Dormann, C.F.: Influence of forest harvest on nitrate concentration in temperate streams - a meta-analysis. Forests 8(5), 1-14 (2017). doi:10.3390/f8010005

42. Egger, M., Davey Smith, G., Schneider, M., Minder, C.: Bias in meta-analysis detected by a simple, graphical test. BMJ Clinical Research 315(7109), 629-34 (1997). doi:10.1136/bmj.316.7129.469

43. Akbulut, S., Keten, A., Stamps, W.T.: Effect of alley cropping on crops and arthropod diversity in Duzce, Turkey. Journal of Agronomy and Crop Science 189(4), 261-269 (2003). doi:10.1046/j.1439-037X.2003.00042.x

44. Mannu, R., Pilia, O., Leonarda, M., Marcello, F.: Variability of beetle assemblages in Mediterranean cork oak woodlands : does the higher taxa approach reliably characterize a specific response to grazing? Biodiversity and Conservation 27(14), 3599-3619 (2018). doi:10.1007/s10531-018-1616-9

45. Peng, R.K., Incoll, L.D., Sutton, S.L., Wright, C., Chadwick, A.: Diversity of airborne arthropods in a silvoarable agroforestry system. Journal of Applied Ecology 30, 551-562 (1993)

46. Peng, R.K., Sutton, S.L.: The activity and diversity of ground arthropods in an agroforestry system. Proceedings of the 49th New Zealand Plant Protection Conference, 309-313 (1996)

47. Stoate, C., Araújo, M., Borralho, R.: Conservation of European farmland birds: abundance and species diversity. Ornis Hungarica 12-13(Tucker 1999), 33-40 (2003)

48. Hill, D.A., Lambton, S., Proctor, I., Bullock, I., Hill, D.A.: Winter bird communities in woodland in the forest of Dean, England, and some implications of livestock grazing. Bird Study 38(1), 57-70 (1991). doi:10.1080/00063659109477068

49. Rösch, V., Hoffmann, M., Diehl, U., Entling, M.H.: The value of newly created wood pastures for bird and grasshopper conservation. Biological Conservation (2019). doi:10.1016/j.biocon.2019.07.036

50. Garrido-Jurado, I., Fernández-bravo, M., Campos, C., Quesada-moraga, E.: Diversity of entomopathogenic Hypocreales in soil and phylloplanes of five Mediterranean cropping systems. Journal of Invertebrate Pathology 130, 97-106 (2015). doi:10.1016/j.jip.2015.06.001

51. Rossetti, I., Bagella, S., Cappai, C., Caria, M.C., Lai, R., Roggero, P.P., Martins da Silva, P., Sousa, J.P., Querner, P., Seddaiu, G.: Isolated cork oak trees affect soil properties and biodiversity in a Mediterranean wooded grassland. Agriculture, Ecosystems and Environment 202, 203-216 (2015). doi:10.1016/j.agee.2015.01.008

52. Obrist, M.K., Rathey, E., Bontadina, F., Martinoli, A., Conedera, M., Christe, P., Moretti, M.: Response of bat species to sylvo-pastoral abandonment. Forest Ecology and Management 261(3), 789-798 (2011). doi:10.1016/j.foreco.2010.12.010

53. Plieninger, T., Hui, C., Gaertner, M., Huntsinger, L.: The impact of land abandonment on species richness and abundance 
in the Mediterranean Basin: A meta-analysis. PLoS ONE 9(5) (2014). doi:10.1371/journal.pone.0098355

54. Barriga, J.C., Lassaletta, L., Moreno, A.G.: Ground-living spider assemblages from Mediterranean habitats under different management conditions. Journal of Arachnology 38(2), 258-269 (2010). doi:10.1636/P09-40.1

55. Mcadam, J.H., Sibbald, A.R., Teklehaimanot, Z., Eason, W.R.: Developing silvopastoral systems and their effects on diversity of fauna. Agroforestry Systems 70(1), 81-89 (2007). doi:10.1007/s10457-007-9047-8

56. Haggar, J., Pons, D., Saenz, L., Vides, M.: Contribution of agroforestry systems to sustaining biodiversity in fragmented forest landscapes. Agriculture, Ecosystems and Environment 283(June), 106567 (2019). doi:10.1016/j.agee.2019.06.006

57. Batáry, P., Gallé, R., Riesch, F., Fischer, C., Dormann, C.F., Mußhoff, O., Császár, P., Fusaro, S., Gayer, C., Happe, A.K., Kurucz, K., Molnár, D., Rösch, V., Wietzke, A., Tscharntke, T.: The former Iron Curtain still drives biodiversity-profit trade-offs in German agriculture. Nature Ecology and Evolution 1(9), 1279-1284 (2017). doi:10.1038/s41559-017-0272-x

58. Gonthier, D.J., Ennis, K.K., Farinas, S., Hsieh, H.-y., Tscharntke, T., Iverson, A.L., Cardinale, B.J., Perfecto, I.: Biodiversity conservation in agriculture requires a multi-scale approach. Proceedings of the Royal Society B 281, 20141358 (2014)

59. Hass, A.L., Kormann, U.G., Tscharntke, T., Clough, Y., Fahrig, L., Martin, J.-L., Baillod, A.B., Baudry, J., Bertrand, C., Bosch, J., Brotons, L., Burel, F., Georges, R., Giralt, D., Marcos-Garcia, M.A., Ricarte, A., Siriwardena, G., Batary, P.: Landscape configurational heterogeneity by small-scale agriculture, not crop diversity, maintains pollinators and plant reproduction in western Europe. Proceedings of the Royal Society B 285, 20172242 (2018). doi:10.1098/rspb.2017.2242

60. Jowett, K., Milne, A.E., Metcalfe, H., Hassall, K.L., Potts, S.G., Senapathi, D., Storkey, J.: Species matter when considering landscape effects on carabid distributions. Agriculture, Ecosystems and Environment 285(January), 106631 (2019). doi:10.1016/j.agee.2019.106631

61. Slancarova, J., Garcia-Pereira, P., Fric, Z.F., Romo, H., Garcia-Barros, E.: Butterflies in Portuguese 'montados': relationships between climate, land use and life-history traits. Journal of Insect Conservation 19(5), 823-836 (2015). doi:10.1007/s10841-015-9801-6

62. Dicks, L.V., Walsh, J.C., Sutherland, W.J.: Organising evidence for environmental management decisions: a '4S' hierarchy. Trends in Ecology \& Evolution 29(11), 1-7 (2014). doi:10.1016/j.tree.2014.09.004

63. Pullin, A.S., Knight, T.M.: Support for decision making in conservation practice: an evidence-based approach. Journal for Nature Conservation 11(2), 83-90 (2003)

64. Christie, A.P., Amano, T., Martin, P.A., Shackelford, G.E., Simmons, B.I., Sutherland, W.J.: Simple study designs in ecology produce inaccurate estimates of biodiversity responses. Journal of Applied Ecology 56(12), 2742-2754 (2019). doi:10.1111/1365-2664.13499

65. Mupepele, A.-C., Dormann, C.F.: Environmental management: Synthesize evidence to steer decisions. Nature 529(7587), 466-466 (2016). doi:10.1038/529466b

66. Koricheva, J., Kulinskaya, E.: Temporal instability of evidence base: a threat to policy making? Trends in Ecology \& Evolution 34(10), 895-902 (2019). doi:10.1016/j.tree.2019.05.006

67. Grainger, M.J., Bolam, F.C., Stewart, G.B., Nilsen, E.B.: Evidence synthesis for tackling research waste. Nature Ecology \& Evolution (2020). doi:10.1038/s41559-020-1141-6

68. Baker, M.: Is there a reproducibility crisis? Nature 533, 452-454 (2016). doi:10.1038/533452a

69. Editorial: Checklists work to improve science. Nature 556(7701), 273-274 (2018). doi:10.1038/d41586-018-04590-7

70. Azul, A.M., Castro, P., Sousa, J.P., Freitas, H.: Diversity and fruiting patterns of ectomycorrhizal and saprobic fungi as indicators of land-use severity in managed woodlands dominated by Quercus suber- a case study from southern Portugal Anabela. Canadian Journal of Forest Research 39, 2404-2417 (2009). doi:10.1139/X09-148

71. García-Tejero, S., Taboada, Á., Tárrega, R., Salgado, J.M.: Land use changes and ground dwelling beetle conservation in extensive grazing dehesa systems of north-west Spain. Biological Conservation 161, 58-66 (2013). doi:10.1016/j.biocon.2013.02.017

72. Moss, R.H.: The IPCC: Policy relevant (not driven) scientific assessment. A comment on Sonja Boehmer-Christiansen's: Global climate protection policy: The limits of scientific advice'. Global Environmental Change 5(3), 171-174 (1995). doi:10.1016/0959-3780(95)00058-V

73. Larigauderie, A., Mooney, H.A.: The Intergovernmental science-policy Platform on Biodiversity and Ecosystem Services: Moving a step closer to an IPCC-like mechanism for biodiversity. Current Opinion in Environmental Sustainability 2(1-2), 9-14 (2010). doi:10.1016/j.cosust.2010.02.006

74. Moher, D., Liberati, A., Tetzlaff, J., Altman, D.G.: Preferred Reporting Items for Systematic Reviews and Meta-Analyses: The PRISMA Statement. PLoS Medicine 6(7), 1000097 (2009). doi:10.1371/journal.pmed.1000097 
bioRxiv preprint doi: https://doi.org/10.1101/2020.08.27.269589; this version posted August 28, 2020. The copyright holder for this preprint (which was not certified by peer review) is the author/funder, who has granted bioRxiv a license to display the preprint in perpetuity. It is made available under aCC-BY-NC 4.0 International license.

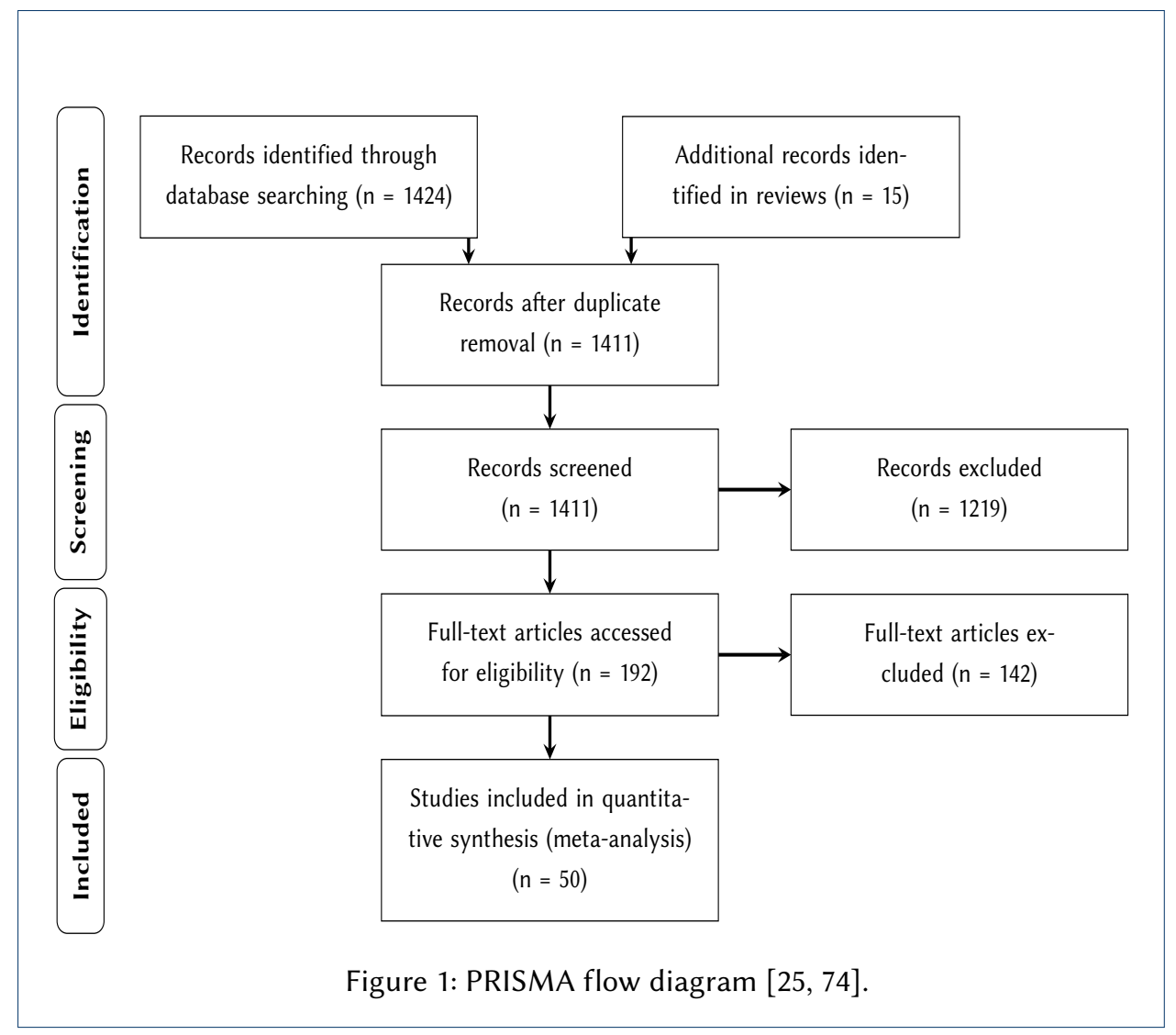

Figures 
bioRxiv preprint doi: https://doi.org/10.1101/2020.08.27.269589; this version posted August 28, 2020. The copyright holder for this preprint (which was not certified by peer review) is the author/funder, who has granted bioRxiv a license to display the preprint in perpetuity. It is made available under aCC-BY-NC 4.0 International license.

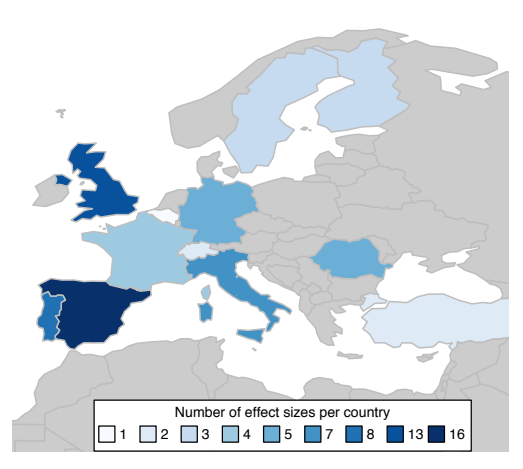

Figure 2: Map of Europe with the number of effect sizes per country.

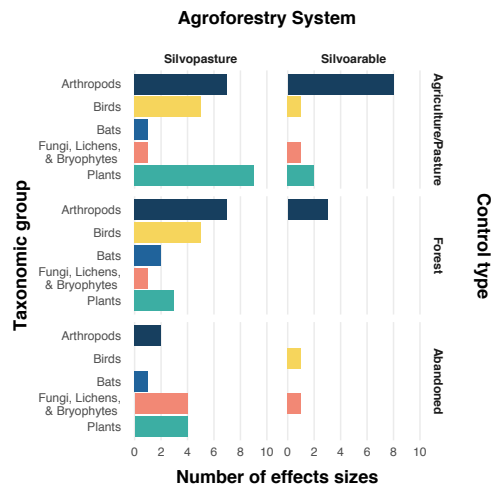

Figure 3: Number of effect sizes in each combination of agroforestry system, comparator and biodiversity group.

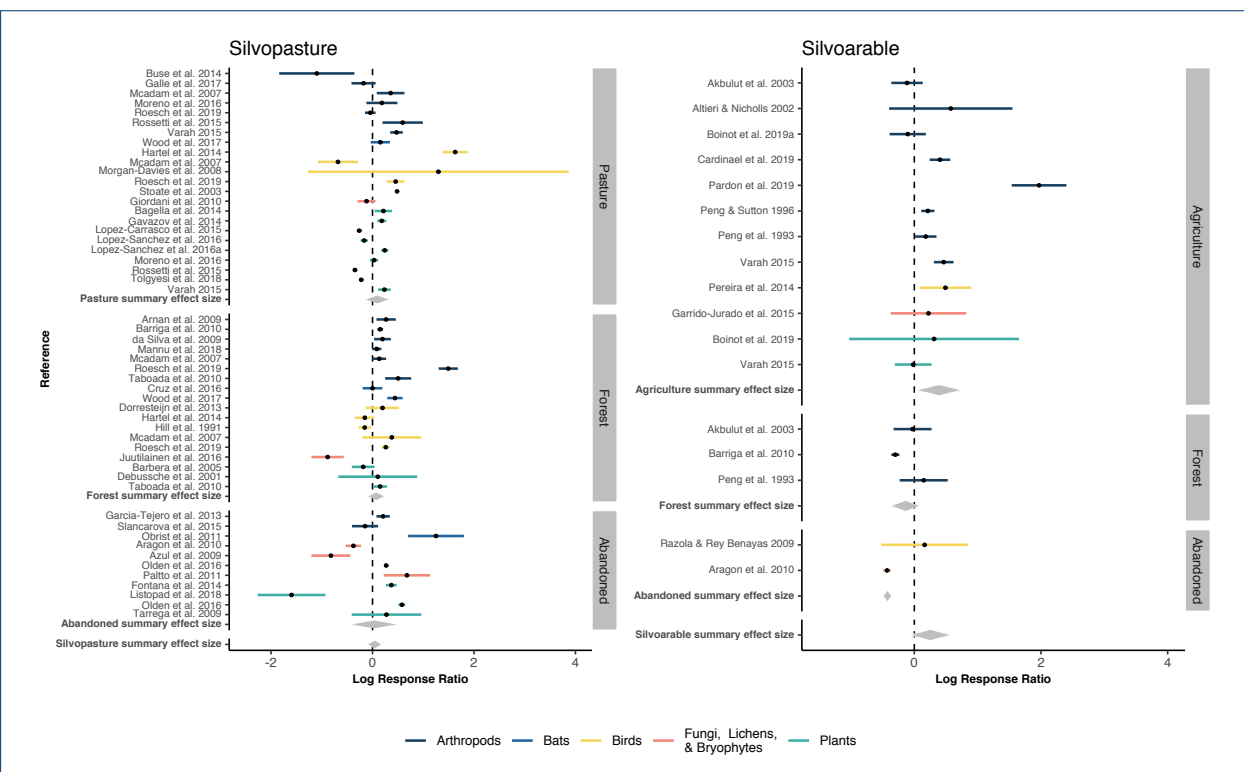

Figure 4: Forest plot for silvopasture and silvoarable systems with subgroup summary effect sizes (grey diamonds) per system (silvoarable, silvopastoral) and per control type (pasture/conventional agriculture, forest or abandoned agroforestry system). 
bioRxiv preprint doi: https://doi.org/10.1101/2020.08.27.269589; this version posted August 28, 2020. The copyright holder for this preprint (which was not certified by peer review) is the author/funder, who has granted bioRxiv a license to display the preprint in perpetuity. It is made available under aCC-BY-NC 4.0 International license.

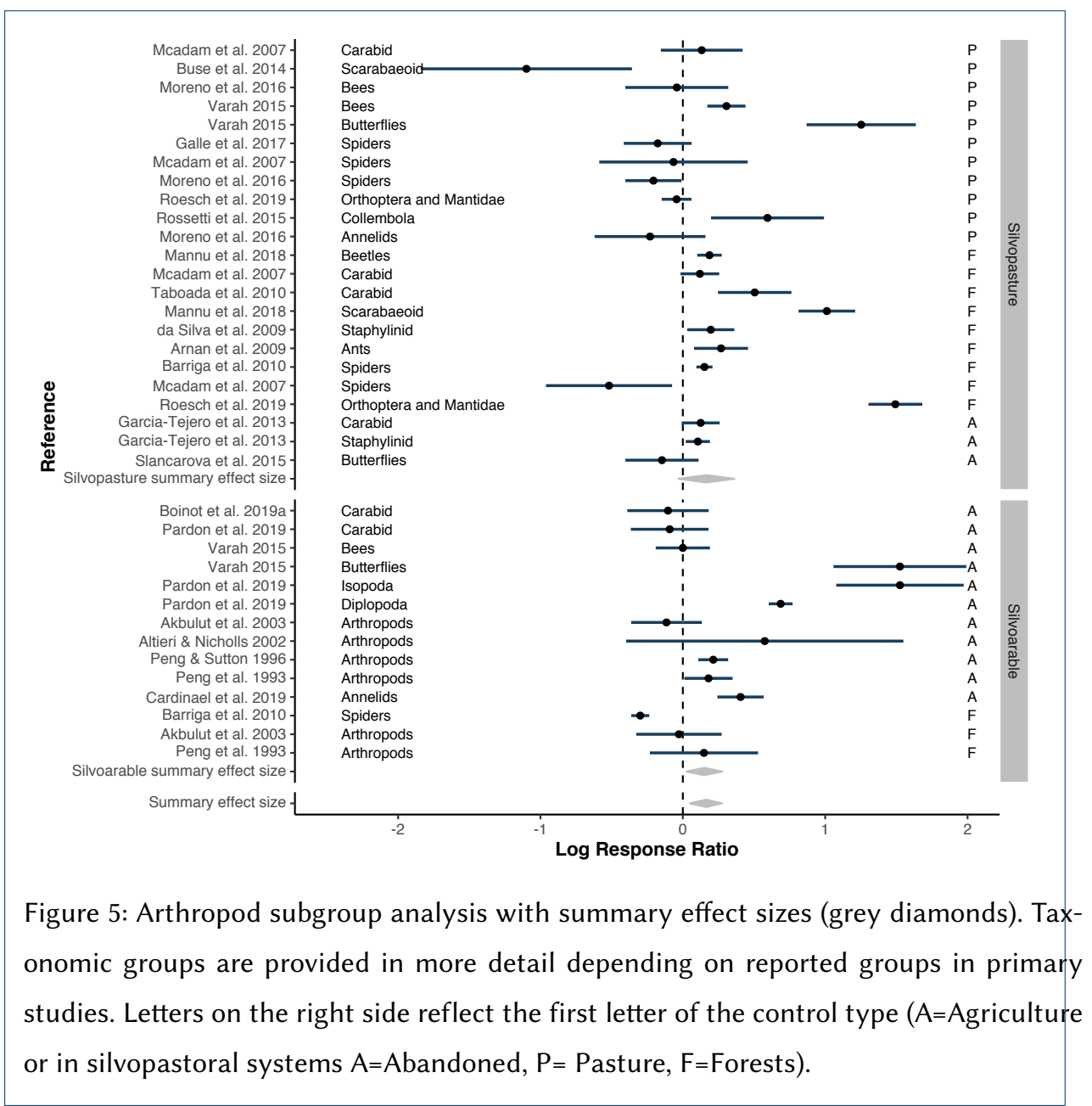


bioRxiv preprint doi: https://doi.org/10.1101/2020.08.27.269589; this version posted August 28, 2020. The copyright holder for this preprint (which was not certified by peer review) is the author/funder, who has granted bioRxiv a license to display the preprint in perpetuity. It is made available under aCC-BY-NC 4.0 International license.

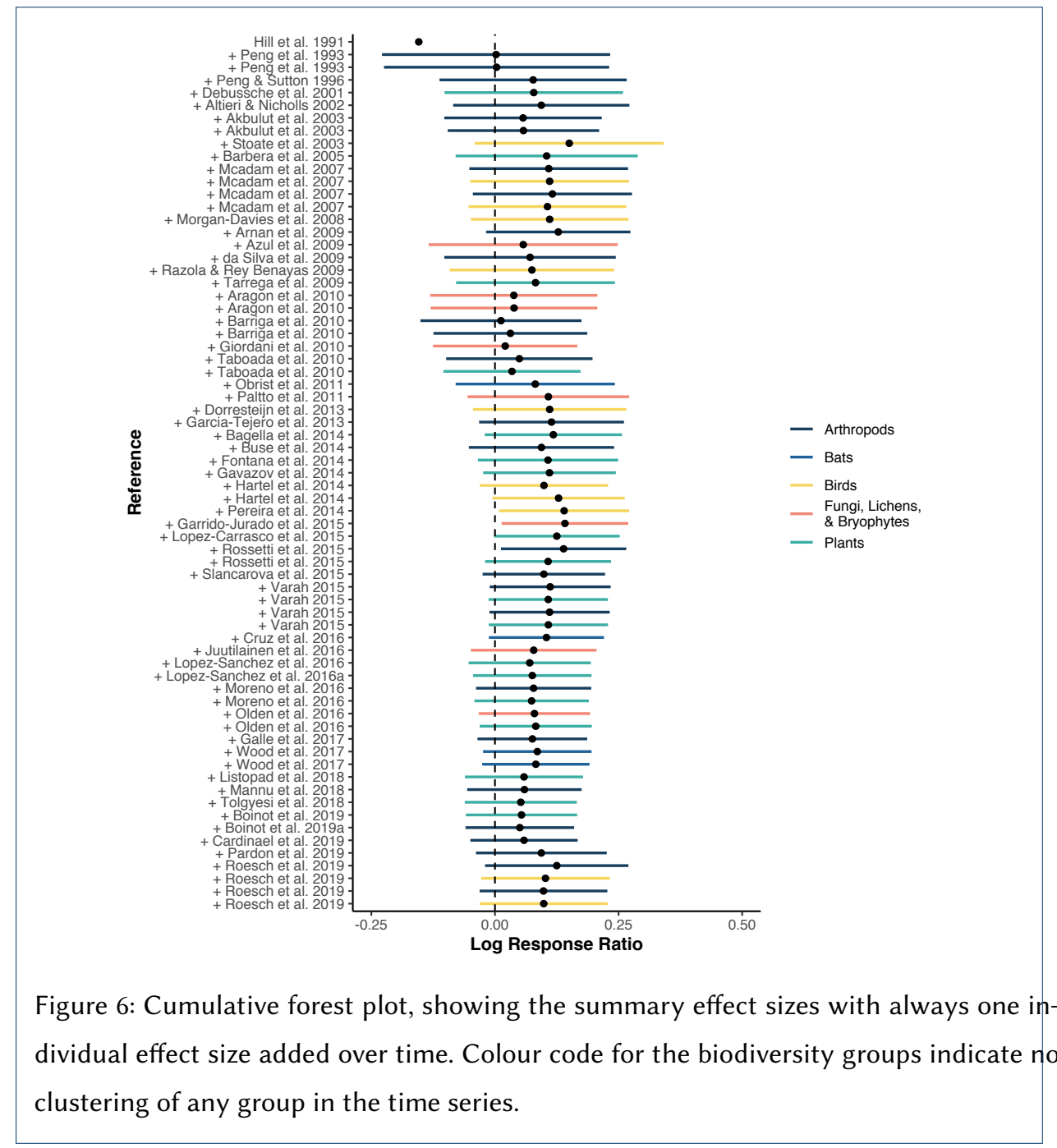


bioRxiv preprint doi: https://doi.org/10.1101/2020.08.27.269589; this version posted August 28, 2020. The copyright holder for this preprint (which was not certified by peer review) is the author/funder, who has granted bioRxiv a license to display the preprint in perpetuity. It is made available under aCC-BY-NC 4.0 International license.

Mupepele et al.

Page 17 of 18

Tables

Table 1: Environmental variables

\begin{tabular}{l|l} 
Variable name & Categories \\
\hline $\begin{array}{l}\text { agroforestry system } \\
\text { control type }\end{array}$ & $\begin{array}{l}\text { silvopastoral; silvoarable } \\
\text { forest, (conventional) agriculture (i.e. pure crop fields), pasture or abandoned } \\
\text { agroforestry systems (generally described as shrub-encroached) } \\
\text { transects with sweep netting; pitfall traps; pan traps; recording and various } \\
\text { other methods } \\
\text { species richness, family richness or Shannon diversity } \\
\text { diversity measure } \\
\text { sampling year } \\
\text { country of study location } \\
\text { climate zone }\end{array}$ \\
$\begin{array}{l}\text { European country } \\
\text { Mediterranean (including two summer-moist Atlantic studies), temperate Cen- } \\
\text { tral European or boreal }\end{array}$
\end{tabular}


bioRxiv preprint doi: https://doi.org/10.1101/2020.08.27.269589; this version posted August 28, 2020. The copyright holder for this preprint (which was not certified by peer review) is the author/funder, who has granted bioRxiv a license to display the preprint in perpetuity. It is made available under aCC-BY-NC 4.0 International license.

Mupepele et al.

Page 18 of 18

Additional Files

Additional Files will be provided upon request. 